\title{
POSSIBLE LATE PALAEOZOIC GLACIATION IN THE GENTRAL PARTS OF THE YEMEN ARAB REPUBLIC
}

\author{
By Hamed A. EL-NaKhal \\ (Department of Geology, University of Sana'a, Sana'a, Yemen Arab Republic)
}

\begin{abstract}
Occasional outsize clasts, some of which are striated, and laminae bent against the enclosed clasts have been recorded throughout the shales and siltstones forming the lower part of the Kohlan Group in the central parts of the Yemen Arab Republic. Such features are interpreted as an indication of continental glaciation. On stratigraphical grounds, these shales and siltstones are assigned to the Permian.
\end{abstract}

RÉsumÉ. Une possible glaciation paleozoïque lardive dans la partie centrale de la République arabe du Yemen. Des inclusions de gros blocs, certains striés, et des lamelles incurvées autour des blocs inclus ont été repérés dans les schistes et les grès formant l'assise inférieure du Groupe de Kohlan dans le Centre de la République arabe du Yemen. On interprète ces faits comme l'indice

\section{IN TRODUCTION}

In the course of a recent investigation of the stratigraphy and sedimentology of the Kohlan Group, exposures were studied in the outcrop area bordering Kohlan town in the central part of the Yemen Arab Republic, about $65 \mathrm{~km}$ north-west of the city of Sana'a (Fig. 1). In this region the succession is well exposed in both the Khalagah district and at Beit al-Kooli village which lie about $2 \mathrm{~km}$ north and west of Kohlan town, respectively (Fig. 1), forming an area of about $10 \mathrm{~km}^{2}$. Here, the lower part of the Kohlan Group consists of a thick succession of rhythmically laminated silt-shale and banded sandy siltstone interbeds with some features indicative of a glacial origin, such as outsize clasts (heterogeneous clasts which are clearly distinguishable and of a much larger size than the grains of the host rock), striated boulders and laminae bent against the enclosed clasts. This study is devoted mainly to the

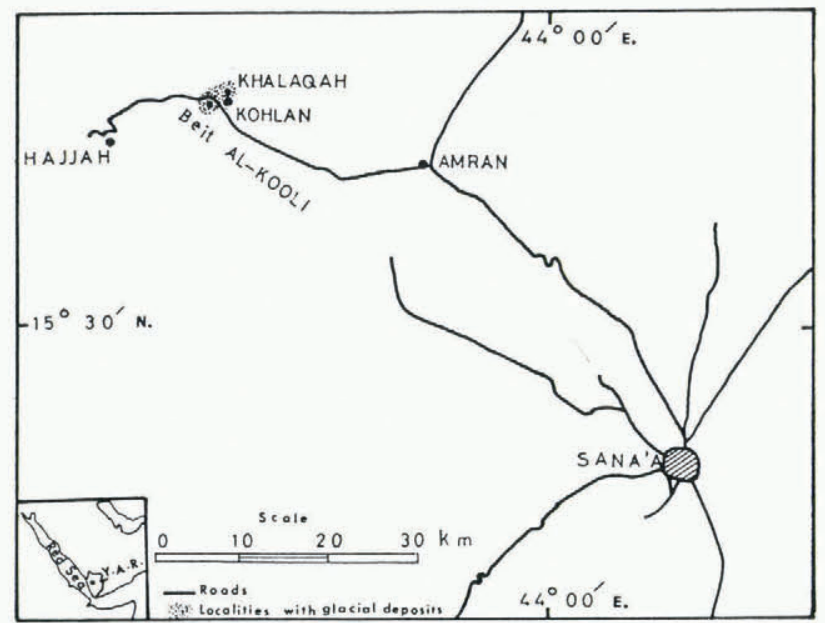

Fig. 1. Location map showing the area with glacial deposits in the central parts of the Yemen Arab Republic. The inset indicates the position of the Yemen Arab Republic in relation to the Arabian Peninsula. d'une glaciation continentale. Du point de vue stratigraphique ces schistes et grès sont attribués au Permien.

Zusammenfassung. Spätpaläozoische Vereisung in den zentralen Teilen der Arabischen Republik Yemen. In den Schiefer- und Schlammlagen, die den unteren Teil der Kohlan-Gruppe in den zentralen Teilen der Arabischen Republik Yemen bilden, wurden gelegentlich grössere, manchmal gekritzte Gesteinsbrocken und Lamellen, die gegen die eingeschlossenen Bruchstücke gebogen sind, festgestellt. Solche Erscheinungen werden als Anzeichen einer festländischen Vereisung gedeutet. Aus stratigraphischen Gründen werden die Schiefer- und Schlammschichten dem Perm zugeordnet.

description and discussion of these features and their significance.

\section{Historical review}

Late Palaeozoic glaciation in the southern parts of the Arabian Peninsula was first recorded by Hudson (1958) and Morton ([1959]), who described glacial deposits of a late Carboniferous-early Permian age from Oman. This record has recently been confirmed by Braakman and others (1982). Similar deposits in the upper part of the Wajid Sandstone (Permian or older ?) in the Bani Khatmah area, south-western Saudi Arabia, were recorded by Helal $(1963,1965)$ and McClure (in Braakman and others, 1982). Roland (1978) described the occurrence of striated erratic boulders in the lower shales of the Kohlan Group at Wadi Akbra near the Sa'dah area, northern Yemen Arab Republic. He explained these boulders as ice-rafted glacial material and he considered the shales of Wadi Akbra as late Palaeozoic in age.

\section{STRATIGRAPHY}

In the study area, the lower part of the Kohlan Group consists of about $110 \mathrm{~m}$ of silt-shale with siltstone interbeds. Here, as elsewhere in the central parts of the Yemen Arab Republic, these shales and siltstones rest unconformably on the Precambrian basement rocks. In turn, this succession is unconformably overlain by a sequence of fine- to medium-grained light-coloured sandstones, which form the upper part of the Kohlan Group. The succession can be subdivided into two main units, which from the base to the top are as follows (Fig. 2):

(a) The lower unit consists of $2.5 \mathrm{~m}$ of alternating thin beds of light grey claystone, dark green siltstone and silt-shale, overlain by $5 \mathrm{~m}$ of dark green rhythmically laminated and highly weathered silt-shale, followed upwards by about $10 \mathrm{~m}$ of light green siltstone. Occasional outsize clasts, some of which are striated (Fig. 3), occur throughout this unit which is about $17.5 \mathrm{~m}$ thick.

(b) The upper unit consists of about $0.5 \mathrm{~m}$ of alternating thin beds of light grey claystone and dark green silt-shale with abundant outsize clasts 


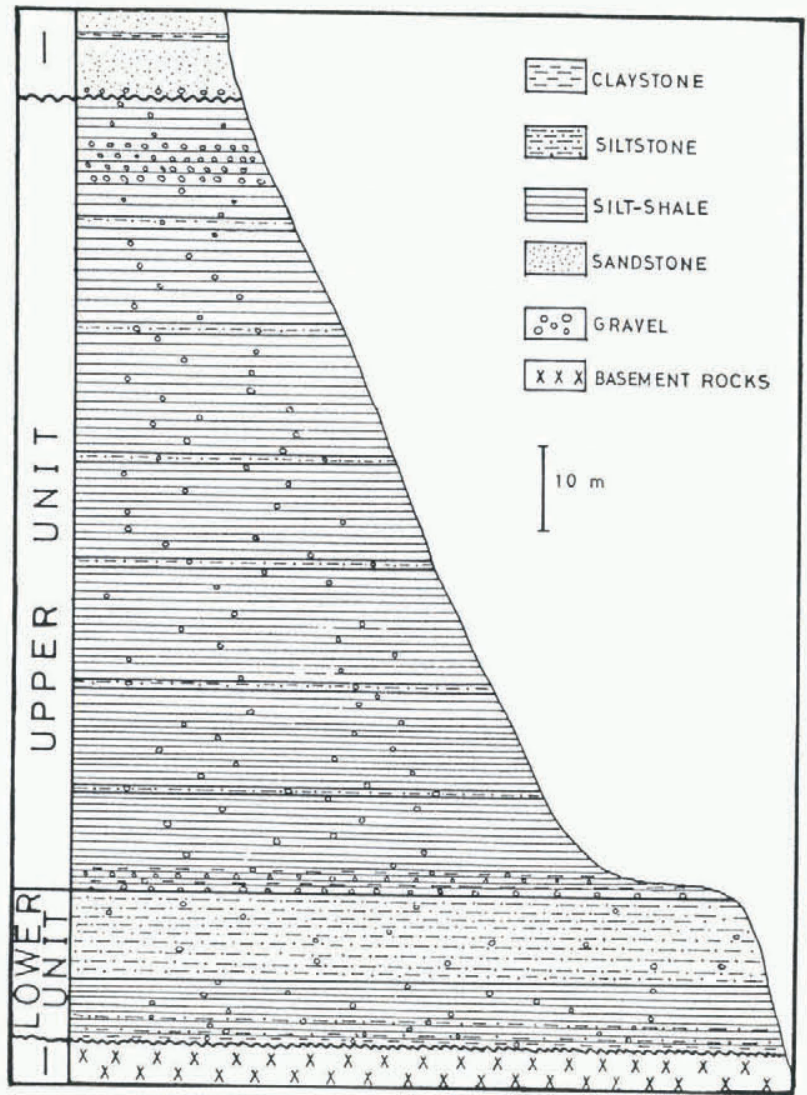

Fig. 2. A measured section through the lower shaly and silty part of the Kohlan Group; Beit al-Kooli village, Yemen Arab Republic.

(Fig. 4), overlain by a thick sequence of rhythmically laminated dark green to black, highly weathered silt-shale with numerous intercalations of thin interbeds of light grey, compact banded sandy siltstone. The exposed lower horizons of this unit have three joint sets (Fig. 5). Occasional outsize clasts have been observed throughout the sequence. The uppermost $8 \mathrm{~m}$ of this unit contain abundant clasts. The total thickness of this unit is about $92.5 \mathrm{~m}$.

\section{FEATURES INDICATIVE OF GLACIATION}

The shales and siltstones of the Kohlan Group possess certain features which can be considered as indicative of glaciation:

(a) Outsize clasts. Occasional clasts of granitic and metamorphic basement rocks occur throughout the succession. These clasts have a wide range of particle size and morphology; many of them have a size much larger than that of the grains of the shales and siltstones containing them (Figs 3,4 , and 6 ). These are interpreted as glacial deposits.

(b) Striated boulders. Some of the recorded clasts are striated (Fig. 3). The largest striated clast observed in this area is about $5 \mathrm{~m}$ long; it is an elongated boulder of coarse pink granite (Fig. 3b). These striations are attributed to a glacial origin.

(c) Bent laminae. In some cases, the laminae of the silt-shale are deformed and bent against the enclosed clasts (Fig. 6). This suggests that the clasts were rafted out by floating ice and dropped (cf. Lahee, 1961, p. 71); they are therefore interpreted as dropstones from an iceberg.
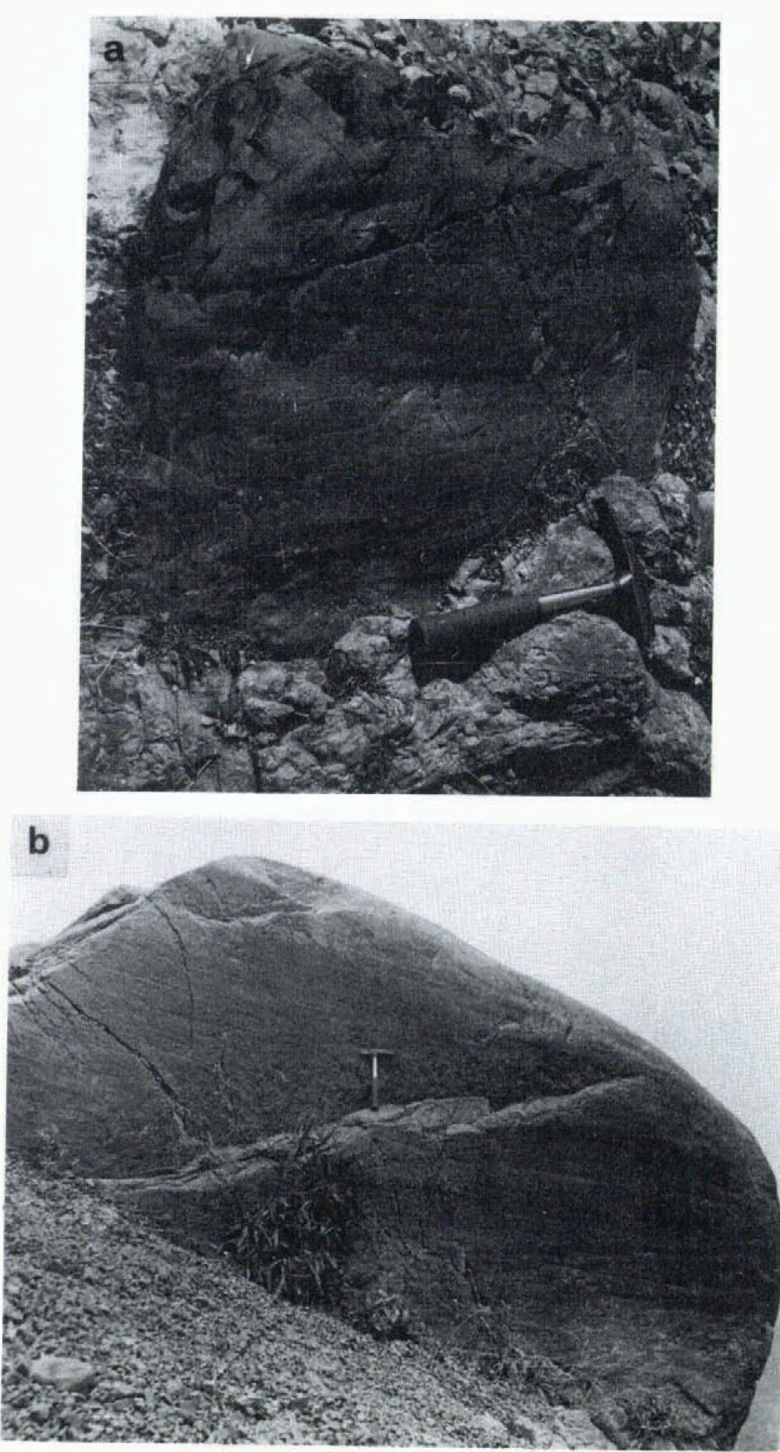

Fig. 3. Striated boulders: (a) From the Khalaqah district; (b) The largest striated boulder recorded in the study area; its length is more than $5 \mathrm{~m}$; Beit al-Kooli village.

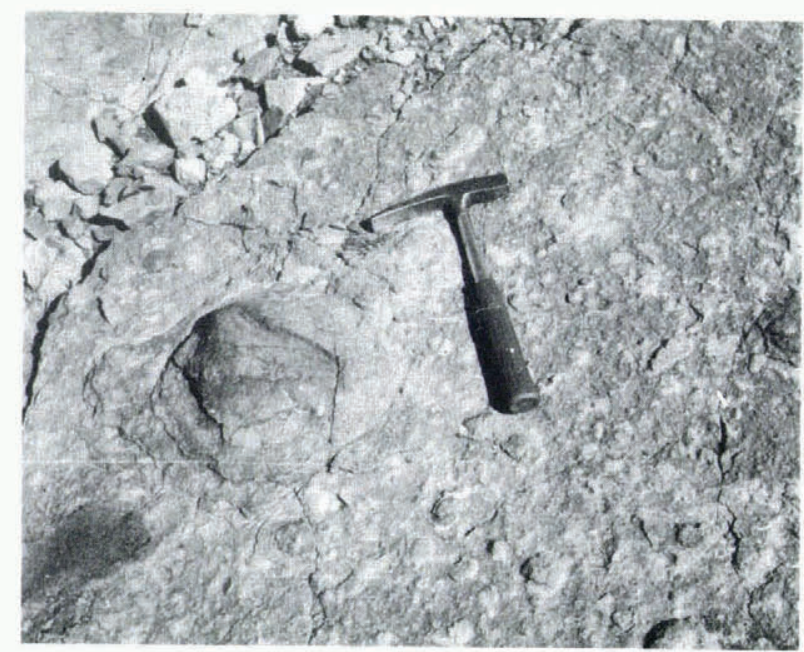

Fig. 4. Exposure of a thin clast-rich bed; Beit alKooli village. 


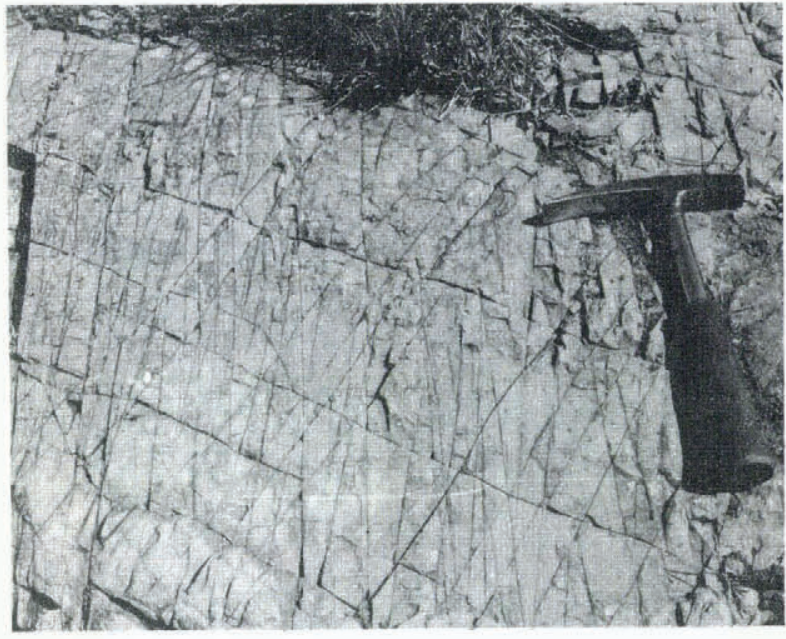

Fig. 5. Three joint sets on a pavement of light grey claystone; Khalaqah district.

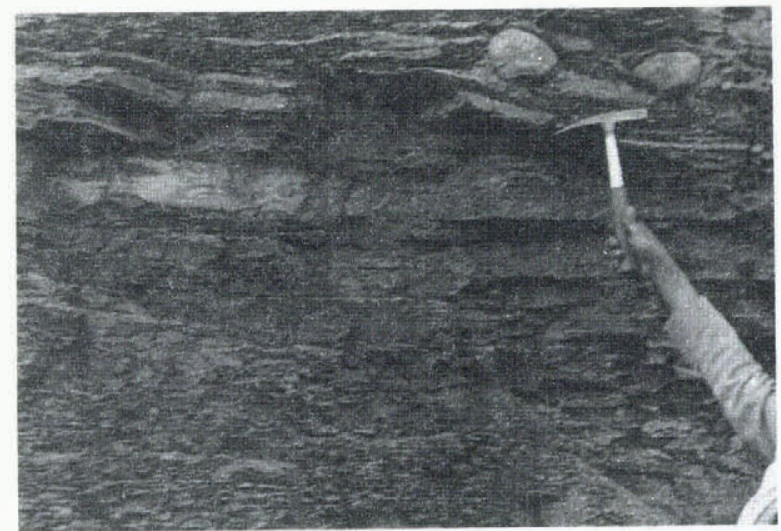

Fig. 6. Section through the rhythmically laminated dark green silt-shale, showing laminae bent against the enclosed clasts; Kohlan al-Soq.

AGE

The clast-bearing shales and siltstones belong to and form the lower part of the Kohlan Group. These beds have yielded no fossils and therefore their age depends on their stratigraphical position. This unit is unconformably overlain by sandstones of the Kohlan Group from which Carpentier and Lamare (1932) recorded plant fossils of a Liassic age. In the northern part of the Yemen, the shales and siltstones of the Kohlan Group overlie the Wajid Sandstone. Both Helal (1963, 1965) and McClure (in Braakman and others, 1982) assigned the upper Wajid Formation to a late Carboniferous-early Permian age. Therefore, the shaly and silty sequence of the Kohlan Group can be bracketed between the early Permian and the Liassic, which means that this sequence is equivalent to the Gondwana glacial deposits of other regions. However, due to the fact that the shaly and sandy units of the Kohlan Group are separated by an unconformity, the hiatus of which cannot be estimated because the adjacent strata lack fossils, the Triassic may be either partly or completely absent from the Kohlan Group succession. Therefore, the clast-bearing shales and siltstones are tentatively assigned to the late Permian, whereas the overlying sandstones are considered to be Triassic (?)-Liassic in age.

\section{SUMMARY AND CONCLUSIONS}

The occurrence of outsize clasts, together with striated boulders and bent laminae throughout this succession, has led to the following conclusions:

1. The occurrence of the above features indicates that the shales and siltstones of the lower part of the Kohlan Group of the Yemen were deposited in a glaciomarine or glaciolacustrine environment.

2. The presence of possible glacial deposits in this succession is considered to be an indication that the late Palaeozoic Gondwana glaciation affected the southern Arabian Peninsula.

3. On stratigraphical grounds, the lower shaly and silty unit of the Kohlan Group is tentatively assigned to the Permian, whereas the upper sandy unit is considered to be Triassic (?)-Liassic in age.

\section{REFERENCES}

Braakman, J.H., and others. 1982. Late Palaeozoic Gondwana glaciation in Oman, by J.H. Braakman, B.K. Levell, J.H. Martin, T.L. Potter, and A. van Vliet Nature, Vol . 299, No. 5878, p. 48-50.

Carpentier, C.A., and Lamare, P. 1932. Végétaux fossiles du Yémen. Bulletin de la Société Géologique de France, Sér. 5, Tom. 2, p. 83-92.

Helal, A.H. 1963. Jungpaläozoische Glazialspuren auf dem Arabischen Schild. Eiszeitalter und Gegenwart, Bd. 14, p. 121-23.

Helal, A.H. 1965. On the occurrence and stratigraphic position of Permo-Carboniferous tillites in Saudi Arabia. Geologische Rundschau, Bd. 54, Ht. 1, p. 193-207.

Hudson, R.G.S. 1958. [Contribution to] Discussion. (In King, 1958, p. 70-71.)

King, L.C. 1958. Basic palaeogeography of Gondwanaland during the late Palaeozoic and Mesozoic eras. Quarterly Journal of the Geological Society of London, Vol. 114, Pt. 1, p. 47-77.

Lahee, F.H. 1961. Field geology. Sixth edition. New York, McGraw-Hill Book Co., Inc.

Morton, D.M. [1959.] The geology of Oman. Fifth World Petrolewn Congress, New York, 1959. Proceedings, Sec. 1 [i.e. Vol. 1], p. 277-94.

Roland, N.W. 1978. Jungpaläozoische Glazialspuren auf dem Arabischen Schild. Eiszeitalter und Gegenwart, Bd. 28, p. 133-38. 